DOI: $10.21802 / \operatorname{artm} .2020 .1 .13 .43$.

УДК 617.55-001-06:616.14-005.6/.7] - 037

\title{
ДИНАМІЧНА ПРОГНОСТИЧНА ШКАЛА ВИЗНАЧЕННЯ СТУПЕНЯ РИЗИКУ ВЕНОЗНИХ ТРОМБОЗІВ ТА ЕМБОЛІЙ У ПАЦІЕНТІВ 3 ІЗОЛЬОВАНОЮ ТА ТЯЖКОЮ ПОЕДНАНОЮ ТРАВМОЮ ЖИВОТА
}

\author{
Р.Л. Бохонко ${ }^{1}$ О.Б. Матвійчук ${ }^{1}$, Я.А. Король ${ }^{1}$, Н.Р. Федчишин ${ }^{1}$, Т.М. Федоришин ${ }^{2}$ \\ ${ }^{1}$ Львівський національний медичний університет імені Данила Галиџького, кафедра хірургї̈ та \\ ендоскопї факультету післядипломної освіти, м. Львів, Україна, \\ ${ }^{2}$ Комунальне некомериійне підприємство «Клінічна лікарня швидкої медичної допомоги м. Львова», \\ м. Львів, Украӥна, \\ ORCID ID: 0000-0003-3859-0635, ORCID ID: 0000-0002-5864-1535, \\ ORCID ID: 0000-0003-3664-3035, ORCID ID: 0000-0003-0232-2778, \\ ORCID ID: 0000-0002-8683-1221, \\ e-mail:romanbokhonko@gmail.com
}

Резюме. Метою дослідження є покращення результатів лікування пацієнтів з ізольованою та тяжкою поєднаною травми живота (ТПТЖ) шляхом диференційованої профілактики венозних тромбозів та емболій (BTE) шляхом використання опрацьованої динамічної прогностичної шкали визначення ступеня їх ризику.

Матеріали та методи. В основу роботи покладено результати лікування 140 постраждалих ретроспективної, 105 пацієнтів проспективної та 57 травмованих групи проспективного прогнозування 3 ізольованою та ТПТЖ, оперованих у 2005-2017 роках.

Результати дослідження. За ходом виконання дослідження та опрацювання вибірки із 105 пацієнтів проспективної групи з ізольованою й ТПТЖ, верифіковано $27(25,7 \%)$ випадків тромбозу в басейні нижньої порожнистої вени, з яких 10 (37,0\%) проявились клінічно. За 48 показниками методом однофакторного регресійного аналізу виділено 18 предикторів, які мали статистично вірогідний $(\mathrm{p}<0,05)$ вплив. Опрацьовано об'єктивізовану динамічну прогностичну шкалу, яка містить перелік факторів ризику ВТЕ перед операційним втручанням і в післяопераційному періоді, а їх прогностичну значимість виражено у балах.

Висновки. Встановлено 4 незалежних чинники виникнення тромбозу глибоких вен у передопераційному періоді та 3 у післяопераційному періоді. На основі незалежних чинників опрацьовано об'єктивізовану динамічну прогностичну шкалу прогнозування ризику венозних тромбозів та емболій. Впровадження в клініці об'єктивізованої прогностичної динамічної шкали ступеня ризику ВТЕ і відповідне застосування профілактики дозволило суттєво знизити частоту цих ускладнень 3 25,7\% до 7,1\% (p<0,05).

Ключові слова: прогностична динамічна шкала, тромбоз глибоких вен, венозні тромбози та емболії, ізольована травма живота, тяжка поєднана травма живота.

Вступ. Надання медичної допомоги постраждалим 3 ізольованою та тяжкою поєднаною травмою живота (ТПТЖ), діагностика, прогнозування та профілактика ускладнень залишаються першочерговими завданнями для спеціалізованих центрів України і за кордоном. ТПТЖ є третьою (після серцево-судинних та онкологічних захворювань) за частотою причиною летальності і посідає перше місце серед осіб до 40 років $[1,9,15]$.

Венозні тромбози та емболії (ВТЕ) - одне 3 найтяжчих i життєво загрозливих ускладнень у клінічній медицині, яке проявляється тромбозом глибоких вен (ТГВ) та тромбоемболією легеневої артерії (ТЕЛА). Існуючі дані дозволяють стверджувати, що майже у $25 \%$ населення світу в той чи інший період життя виникають ВТЕ. В умовах багатопрофільного стаціонару венозні тромбози виявляють у 15-20 випадків на 1000 пацієнтів. У багатьох травмованих клініка ТГВ нижніх кінцівок і ТЕЛА перебігає безсимптомно. При ТГВ нижніх кінцівок у 75\% спостережень існує прихована ТЕЛА. За даними патолого- анатомічних досліджень, iї виявляють у 7,2-16\% пацієнтів, з яких в 50-100 хворих на 100000 населення за рік вона $є$ причиною смерті. Після хірургічних втручань на органах черевної порожнини та грудної клітки флеботромбоз виникає у 33\% пацієнтів [5,7].

В Україні щорічно реєструють близько 260 випадків ТГВ та їх ускладнень на 100000 населення 3 летальністю від ТЕЛА 20-25\%. Тяжким вислідом ТГВ будь-якої локалізації є посттромботичний синдром, який виникає у 29-79\% хворих, і призводить до формування трофічних виразок у 300 пацієнтів на 100 000 осіб, що становить 25\% від усіх виразок [14,15].

Несвоєчасне встановлення діагнозу ТГВ спричинює високі показники летальності та тривалий перебіг захворювання внаслідок прогресування процесу, ймовірності виникнення ТЕЛА, довготривалого перебігу посттромботичного процесу у 50\% спостережень $[3,4,8]$.

Діагностика ембологенного венозного тромбозу та ТЕЛА, яка не супроводжується тяжкими гемодинамічними розладами, складна 3 огляду на не- 
специфічність симптомів. Водночас раннє виявлення та негайне лікування пацієнта дають можливість врятувати йому життя i попередити віддалені наслідки захворювання [3,6].

ТГВ нижніх кінцівок і ТЕЛА $є$ частими ускладненнями у постраждалих 3 ізольованою та ТПТЖ. Несприятливими факторами у післяопераційному періоді $є$ крововтрата з анемією та гнійносептичні ускладнення. Незважаючи на успіхи діагностики, лікування, профілактики тромбозів, кількість рандомізованих багатоцентрових досліджень цих ускладнень у постраждалих із ТПТЖ є недостатньою, а існуючі світові стандарти i рекомендації мають суперечливий характер $[7,12,13]$.

Статистично доведено, що травмовані мають один 3 найвищих ризиків розвитку ВТЕ. Високий відсоток цього ускладнення пояснюється розвитком коагулопатії споживання, в основі якої лежить дисеміноване внутрішньосудинне зсідання крові, депресія фібринолітичної системи, підвищення тромбопластин-тромбінової активності та зниження концентрації антитромбіну III. Ця стадія короткочасна i швидко може перейти у стадію гіпокоагуляції, яка призводить до тромбоцитопенії та виснаження плазмових коагуляційних факторів, перетворення фібриногену в продукти деградації фібрину і розчинні комплекси мономерів фібрину як наслідок активації фібринолізу. Враховуючи зазначене, оцінити баланс системи гемостазу між гіперкоагуляцією та гіпокоагуляцією (з виснаженням системи тромбоутворення) в умовах невідкладної хірургії у травмованих, оперованих в ургентному порядку з приводу ізольованої та ТПТЖ, i терміни проведення профілактики ВТЕ, надзвичайно складно [3,6,9,10].

Травмованих госпіталізують у стаціонар, в основному, за наявності факторів ризику ВТЕ, проте ускладнення виникає після виконання операції або виписки із стаціонару. Труднощі діагностики, частота й обмежені можливості надання ефективної спеціалізованої медичної допомоги (майже 50\% хворих 3 масивною ТЕЛА помирає впродовж 30 хв. від моменту іiі виникнення) свідчать, що основою у боротьбі з цією патологією є профілактика $[2,11]$.

Тому питання диференційованої профілактики ВТЕ у постраждалих з ізольованою й ТПТЖ потребують подальшого вивчення та опрацювання.

Обгрунтування дослідження. У ході наукового дослідження доведено, що за відсутності профілактики частота ТГВ у пацієнтів 3 ізольованою та ТПТЖ сягає 25,7 \%. Вперше, запропоновано об'єктивізовану динамічну прогностичну шкалу визначення ступеня ризику венозних тромбозів та емболій у травмованих пацієнтів [13,15]. Встановлено, що запровадження даної шкали дало змогу зменшити частоту даних ускладнень. Незважаючи на поступ у діагностиці, лікуванні та профілактиці, кількість рандомізованих багатоцентрових досліджень венозного тромбоемболізму у травмованих $є$ недостатньою, а світові стандарти та рекомендації профілактики мають інколи суперечливий характер $[3,5,6,7,9,11,14]$.

Метою дослідження $є$ покращення результатів лікування пацієнтів 3 ізольованою та ТПТЖ шляхом диференційованої профілактики ВТЕ та ви- користання опрацьованої динамічної прогностичної шкали визначення ступеня їх ризику.

Матеріали та методи. В основу роботи покладено результати обстеження й лікування 140 постраждалих ретроспективної, 105 пацієнтів проспективної та 57 травмованих групи проспективного прогнозування з ізольованою та ТПТЖ, оперованих у Львівському міському центрі торакоабдомінальної травми (на базі 1 хірургічного відділення), у відділеннях травматології, нейрохірургії Львівської комунальної міської клінічної лікарні швидкої медичної допомоги у 2005-2017 роках.

Ретроспективний аналіз охопив період 3 2005 до 2012 року та полягав у аналізі архівних карт стаціонарних хворих, оперованих ургентно 3 приводу ТПТЖ. Серед постраждалих виявлено 42 $(30,0 \%)$ випадки ТГВ. Привертає увагу те, що у 22 (52,4\%) випадках ТГВ нижніх кінцівок верифіковано за допомогою ультразвукового компресійного ангіосканування на 8,2 2, 3 добу, у 20 (47,6\%) на $12,7 \pm 2,1$ добу. У $19(40,4 \%)$ пацієнтів це була випадкова знахідка під час проведення інструментальних методів обстеження. Статистично аналізуючи результати ретроспективної групи, виявлено вірогідні $(\mathrm{p}<0,05)$ причини виникнення ТГВ у хворих з ТПТЖ: вік понад 55 років, час від отримання травми до госпіталізації понад 4 години, показник ISS (S. Baker, 1974) понад 18 балів, післяопераційна іммобілізація (ліжковий режим) понад 48 годин, кількість тромбоцитів понад $285 \times 10^{9} /$ л, тривалість операційного втручання понад 80 хвилин, показник гематокриту понад $51 \%$.

В основу проспективного дослідження покладено обстеження та лікування постраждалих, оперованих в ургентному порядку 3 ізольованою та ТПТЖ за період 2012-2017 років. Наукове дослідження поділено на два етапи. На першому етапі (2012-2016 рр.) його об'єктом стали 105 пацієнтів 3 ізольованою та ТПТЖ, результати аналізу яких лягли в основу створення власної об'єктивізованої динамічної шкали прогнозування оцінки ступеня ризику ВТЕ, адаптованої до умов ургентної хірургії травми. Другий етап (2016-2017 pp.) полягав у апробації шкали прогнозування у 57 оперованих пацієнтів та впровадження $\dddot{11}$ в клінічну практику.

Вік постраждалих, за узагальненими даними обох етапів дослідження, склав 18-72 років (середній - 43,2 $\pm 5,4$ років). Серед відібраних хворих переважали чоловіки - 81 (77,4\%). Лише 16 (15,2\%) постраждалих госпіталізовано впродовж першої «золотої» години після отримання травми.

Діагностичні заходи та операційні втручання усім травмованим виконано в ургентному порядку у терміни, визначені існуючими стандартами і протоколами. На момент госпіталізації 86 (81,9\%) травмованих перебували у стані середньої тяжкості, 19 $(18,1 \%)$ - у тяжкому. У передопераційному періоді було проведено корекцію вітальних функцій 3 урахуванням рекомендацій суміжних спеціалістів. У всіх постраждалих оцінено анестезіологічний ризик 
згідно зі шкалою ASA, відтак із застосуванням інгаляційного або неінгаляційного комбінованого наркозу проведено операційні втручання у 101 (96,2\%) пацієнта, у 4 (3,8\%) - діагностичні заходи, які тривали від 30 до 220 хв. (в середньому - 123,8 442,6 ).

На двох етапах дослідження перед проведенням операції у 143 (88,3\%) пацієнтів діагностовано наявність вільної рідини в черевній порожнині. Проведено операційні втручання: спленектомію у 33 $(24,4 \%)$, спленектомію + дренування плевральної порожнини - у 31 (19,1\%), спленектомію + зашивання розриву брижі тонкої i/або товстої кишки - у 19 $(11,7 \%)$, спленектомію + зашивання розриву/пакінг печінки - у 16 (9,9\%); спленектомію + зашивання розриву діафрагми + дренування плевральної порожнини - у 3 (1,9\%); спленектомію + дренування плевральної порожнини + видалення внутрішньочерепної гематоми - у 3 (1,9\%); спленектомію + зашивання розриву печінки/пакінг + видалення внутрішньочерепної гематоми + дренування плевральної порожнини - у 2 (1,2\%); спленектомію + видалення внутрішньочерепної гематоми + дренування плевральної порожнини + металоостеосинтез великогомілкової кістки - у 1 $(0,6 \%)$; спленектомію + зашивання розриву брижі тонкої кишки + зашивання розриву стінки шлунка + дренування плевральної порожнини - у 1 (0,6\%) пацієнта. В 13 (8,1\%) оперованих виникли післяопераційні ускладнення: шлунково-кишкові кровотечі - у $5(3,0 \%)$, нагноєння післяопераційної рани - у 2 (1,2\%), пневмонія - у 2 (1,2\%) травмованих, гостра кишкова непрохідність - у 2 (1,2\%), внутрішньочеревна кровотеча - у $1(0,6 \%)$ та евентрація - у 1 (0,6\%) пацієнта. У 27 (25,7\%) хворих верифіковано ТГВ нижніх кінцівок.

Усім пацієнтам проведено стандартний спектр лабораторних аналізів, який включав визначення гематологічних (група крові, резус фактор, параметрів гемоглобіну, гематокриту, еритроцитів, тромбоцитів, лейкоцитів, підрахунок лейкоцитарної формули, розширеної гемостазіограми), біохімічних (показники загального білірубіну та білка, сечовини, креатиніну, електролітів, трансаміназ) показників та загального аналізу сечі згідно з використовуваними методиками.

Особливу увагу приділено дослідженню маркерів активації зсідального потенціалу крові. Серед існуючих (фактор VIIa, комплекс тромбінантитромбін, фібринопептид A, фібрин-мономери та D-димери) виокремлено D-димери. Перевагою цього маркеру $є$ відносно висока концентрація, тривалість циркуляції в кров'яному руслі та відображення процесів утворення фібрину.

Дослідження вен нижніх кінцівок та малого тазу проводили на УСГ-апаратах експертного класу: «GE Logiq Book XP» (СШA) та «Siemens Acuson Cypress» (Німеччина) 3 високочастотними лінійними та конвекційними трансдюсерами частотою 5-10 МГц.

Ангіосканування виконували із застосуванням режимів безперервного та імпульсного випромінювання, дуплексного сканування, кольорового та енергетично спрямованого доплерівського зобра- ження. При дослідженні вен надавали перевагу тріплексному режимові сканування, застосовуючи компресійні проби, маневр Valsalva та проби з використанням пневмоманжетки у положенні пацієнта на спині, на животі (у ранньому післяопераційному періоді - в латеропозиції) та стоячи.

Обстеження проводили білатерально поліпозиційно з обов'язковою візуалізацією на всьому протязі підшкірних, поверхневих та глибоких стегнових, підколінних та гомілкових вен, а також суральних вен. Діагностику проводили безпосередньо перед операційним втручанням або у день поміщення в стаціонар, на 3-4 та 8-10 доби після неї.

Бази даних і статистичне опрацювання результатів власних досліджень виконували за допомогою пакету прикладних комп'ютерних програм для аналізу досліджень медично-біологічних і епідеміологічних досліджень STATISTICA ${ }^{\circledR}$ (Stat Soft Inc., USA).

Результати дослідження. За ходом виконання дослідження та опрацювання вибірки із 105 пацієнтів проспективної групи 3 ізольованою й ТПТЖ, яких оперовано за період з 2012 до 2016 рр., верифіковано $27(25,7 \%)$ випадків тромбозу в басейні нижньої порожнистої вени, 3 яких 10 (37,0\%) проявились клінічно, а саме ознаками набряку кінцівки, пастозності та больового синдрому. Решта (17-63,0\%) випадків ТГВ нижніх кінцівок протікали безсимптомно та верифіковані за допомогою ультразвукового компресійного ангіосканування вен нижніх кінцівок. Тромбоз гомілкових та суральних вен перебігав безсимптомно і верифікований у 7 $(25,9 \%)$ випадках, тромбоз підколінної вени - у 4 $(14,8 \%)$, стегнової вени - у $5(18,5 \%)$ та загальної стегнової - у $8(29,6 \%)$ пацієнтів.

У $6(22,2 \%)$ випадках виявлено ембологенну флотацію - верхівка тромба не кріпилась до судинної стінки, вільно зміщувалась під час акту дихання чи при покашлюванні травмованого спостерігалось «обтікання» останньої при кольоровому картуванні у тріплексному режимі. Випадків ретромбозу та клінічно ТЕЛА не виявлено.

Аналіз 48 показників методом однофакторного регресійного аналізу виділив 18 предикторів, які мали статистично вірогідний $(\mathrm{p}<0,05)$ вплив на виникнення ТГВ нижніх кінцівок як у до- так i післяопераційному періодах у пацієнтів 3 ізольованою та ТПТЖ.

При вивченні факторів ризику ВТЕ виявлено достовірне збільшення кількості епізодів венозних тромбозів у хворих старших вікових груп, зокрема, при досягненні 50-річного віку ризик ТГВ зростав вдвічі $(\mathrm{p}<0,05), 62$-річного віку - у 8 разів $(\mathrm{p}<0,05)$.

Сигніфікантне значення у $71,4 \%$ пацієнтів мали епізоди венозного тромбозу, перенесеного в минулому, що є зрозумілим з позиції патогенезу розвитку цих ускладнень.

Аналіз відношення супровідної патології, яку виявлено у 47,1\% хворого, до виникнення ТГВ у післяопераційному періоді встановив достовірний вплив миготливої аритмії (перед операцією - 5,6\% проти 79,8\%, р<0,05, та після неї - 31,1\% проти 8,1\%, 
p<0,05) та серцево-судинної недостатності IIa-III стадії, III-IV функціонального класу (класифікація NYHA (New York Heart Association Functional Classification) (11,1\% проти 79,8\%, p<0,05).

Вивчаючи стандартні лабораторні показники, особливу увагу приділено розширеному дослідженню системи гемостазу. Виокремлено вірогідні показники: час зсідання крові за Lee-White, протромбіновий час, гематокрит, протромбіновий індекс, кількість тромбоцитів.

Вагомий вплив на потенціювання тромбоутворення має індекс маси тіла, причому найвищий зв'язок відзначено у пацієнтів із його показником понад 28, серед яких ТГВ верифіковано у $63 \%$.

Дослідженням доведено, що період часу від отримання травми до госпіталізації понад 6 годин $є$ пороговим для потенціювання процесів тромбоутворення $(\mathrm{p}<0,05)$ внаслідок активації процесів гіповолемії, стресу, больового синдрому та адинамії.

Кореляційний аналіз вказав на пряму високорівневу позитивну залежність між тяжкістю отриманої поєднаної травми (ISS понад 21 бал та AIS (Abbreviated Injury Scale, 1970) понад 3 бали) і ризиком виникнення ВТЕ, що встановлено впродовж перших семи діб перебування хворого у стаціонарі. Враховуючи високий ступінь кореляції післяопераційної іммобілізації (ліжкового режиму) понад 48 годин 3 розвитком ВТЕ, показник впроваджено у загальну об'єктивізовану динамічну прогностичну шкалу визначення ступеня ризику у пацієнтів 3 ізольованою і ТПТЖ.

Суттєвий вплив тривалості операційного втручання на виникнення ВТЕ підтверджено вже при тривалості операції понад 60 хвилин, а при тривалості понад 160 хвилин - ТГВ виявлено більш, ніж у половини травмованих $(\mathrm{p}<0,05)$.

Вірогідні предиктори, встановлені монофаторним аналізом, обчислено регресійним послідовним багатофакторним аналізом Вальда. Числовий діапазон локалізований від $-5,5$ до $+7,5$ у доопераційному та від $-8,5$ до $+6,5$ - в післяопераційному періодах. Максимальні прогностичні значення: час від отримання травми понад 6 годин, тривалість операційного втручання понад 160 хвилин, наявність ВТЕ в анамнезі, вік травмованих понад 50 років, індекс маси тіла понад 28, післяопераційна іммобілізація (ліжковий режим) понад 48 годин, тяжкість поєднаної травми за шкалою ISS понад 21 бал, ізольованої травми за шкалою AIS - понад 3 бали.

За допомогою статистичного аналізу опрацьовано об'єктивізовану динамічну прогностичну шкалу, яка містить перелік факторів ризику ВТЕ перед операційним втручанням і в післяопераційному періоді, а їх прогностичну значимість виражено у балах. Для зручності розрахунок виведено у позитивну шкалу виміру ( табл.1).

Таблиця 1

Об’сктивізована динамічна прогностична шкала оцінки ступеня ризику ВТЕ у постраждалих 3 ізольованою та ТПТЖ

\begin{tabular}{|c|c|c|c|c|}
\hline \multirow{2}{*}{$\begin{array}{l}\text { № } \\
\Pi / \Pi\end{array}$} & \multirow{2}{*}{ Фактори ризику } & \multirow{2}{*}{$\begin{array}{l}\text { Порогові } \\
\text { значення }\end{array}$} & \multicolumn{2}{|c|}{ Кількість балів } \\
\hline & & & перед операцією & після операції \\
\hline \multirow[t]{2}{*}{1.} & \multirow[t]{2}{*}{ Вік, роки } & $<50$ & 0 & 0 \\
\hline & & $\geq 50$ & 5 & 10 \\
\hline \multirow[t]{2}{*}{2.} & \multirow{2}{*}{$\begin{array}{l}\text { Час від отримання травми до госпіталізації, } \\
\text { год. }\end{array}$} & $<6$ & 0 & 0 \\
\hline & & $\geq 6$ & 5 & 5 \\
\hline \multirow[t]{2}{*}{3.} & \multirow[t]{2}{*}{ Венозні тромбози та емболії в анамнезі } & $\mathrm{Hi}$ & 0 & 0 \\
\hline & & так & 10 & 10 \\
\hline \multirow[t]{2}{*}{4.} & \multirow[t]{2}{*}{ Індекс маси тіла } & $<28$ & 0 & 0 \\
\hline & & $\geq 28$ & 0 & 3 \\
\hline \multirow[t]{2}{*}{5.} & \multirow{2}{*}{$\begin{array}{l}\text { Післяопераційна } \\
\text { режим), год. }\end{array}$} & $\leq 48$ & 0 & 0 \\
\hline & & $\geq 48$ & 0 & 10 \\
\hline \multirow[t]{2}{*}{6.} & \multirow[t]{2}{*}{ Тривалість операції, хв. } & $61-160$ & 0 & 5 \\
\hline & & $\geq 160$ & 0 & 10 \\
\hline \multirow[t]{4}{*}{7.} & \multirow[t]{2}{*}{ Тяжкість поєднаної травми за шкалою ISS } & $16-20$ & 0 & 5 \\
\hline & & $\geq 21$ & 10 & 10 \\
\hline & \multirow[t]{2}{*}{ Тяжкість ізольованої травми за шкалою AIS } & $<3$ & 0 & 0 \\
\hline & & $\geq 3$ & 10 & 10 \\
\hline & Сума балів & & & 78 \\
\hline
\end{tabular}

Для встановлення клінічної ефективності об'єктивізовану динамічну прогностичну шкалу оцінки ступеня ризику ВТЕ у травмованих 3 ізольованою та ТПТЖ апробовано на групі, яка включала 57 пацієнтів, госпіталізованих у 2016-2017 pp. без обмежень за віком та статтю, тяжкістю травми понад 16 балів за ISS та понад 2 бали за шкалою AIS, відсутністю ТГВ нижніх кінцівок при поміщенні у стаціонар.
Отож, перед проведенням операційного втручання сума до 10 балів відповідала низькому ступеню ВТЕ (ймовірність ТГВ - до 2\%), від 11 до 20 балів - помірному (ТГВ - до 20\%), понад 20 балів високому (ТГВ - понад 60\%). Відповідно, здійснено розрахунок ступеня ризику після операційного втручання: низький - до 20 балів (ТГВ - 2\%), помірний 20-30 балів (ТГВ - 2-25\%) і високий - понад 30 балів (ймовірність ТГВ - понад 65\%). 
Враховуючи ступінь ризику у пацієнтів групи проспективного прогнозування, опрацьовано та застосовано алгоритм діагностично-лікувальних дій та профілактики ВТЕ. У пацієнтів із низьким ступенем ризику застосовано неспецифічні методи профілактики, які полягали у максимально швидкій активації травмованих після операції, лікувальній фізкультурі. Серед хворих з помірним та високим ступенем ризику застосовано поєднання медикаментних (нефракціонований та низькомолекулярні гепарини) та неспецифічних профілактичних заходів згідно з наказом МО3 України №329 від 15.06.2007 року.

Пацієнтам 3 наявною супровідною патологією проведено заходи, скеровані на компенсацію функції уражених органів та систем.

Обговорення результатів. Підсумовуючи викладене, слід зазначити, що опрацьований спосіб оцінки ризику ТГВ дає можливість здійснити стратифікацію пацієнтів з ізольованою та ТПТЖ за ступенем ризику ВТЕ. Він $є$ інтуїтивно зрозумілим та доступним у більшості хірургічних стаціонарів.

Прогностична шкала $є$ гнучкою у використанні та максимально наближеною до умов ургентної хірургії травми, має низку переваг над описаними у спеціалізованій літературі: розрахунок проводиться за допомогою анамнестичних, клінічних та лабораторних показників, які доступні у більшості хірургічних стаціонарів України; наявна невелика кількість факторів прогнозування $[6,9,13,14]$. Перерахунок суми балів і ступеня ризику ВТЕ у післяопераційному періоді дає змогу своєчасно застосовувати диференційовану профілактику цих ускладнень.

\section{Висновки:}

1. За відсутності профілактики частота ТГВ у пацієнтів з ізольованою та ТПТЖ сягає $25,7 \%$.

2. Встановлено 4 незалежних чинники виникнення тромбозу глибоких вен у передопераційному періоді (вік понад 50 років, час від отримання травми до госпіталізації понад 6 год., індекс маси тіла понад 28, венозні тромбози та емболії в анамнезі) та 3 у післяопераційному періоді (тривалість операції понад 160 хв., тяжкість травми за шкалою ISS понад 21 бал, за шкалою AIS понад 3 бали, післяопераційна іммобілізація (ліжковий режим) понад 48 год.).

3. На основі незалежних чинників опрацьовано об'єктивізовану динамічну прогностичну шкалу прогнозування ризику венозних тромбозів та емболій у пацієнтів $з$ ізольованою та тяжкою поєднаною травмою живота, та виокремлено легкий, помірний і високий ступінь ризику (чутливість - 83,3\%, специфічність $-76,5 \%)$.

4. Впровадження в клініці об'єктивізованої прогностичної динамічної шкали ступеня ризику ВТЕ і відповідне застосування профілактики дозволило суттево знизити частоту цих ускладнень.

\section{References:}

1. Rossaint R, Bouillon V, Cerny J, Coats J, Duranteau E, Fernández-Mondéjar B. et al. The European guideline on management of major bleeding and coagulopathy following trauma: fourth edition. Critical
Care. 2016; 20:100-24. doi: 10.1186/s13054-0161265-x.

2. Afshari A, Fenger-Eriksen C, Monreal M, Verhamme P. European guidelines on perioperative venous thromboembolism prophylaxis: Mechanical prophylaxis. European Journal of Anaesthesiology. 2018; 35(2):77-83. doi: 10.1097/EJA.0000000000000726.

3. Ahmed A, Kozek-Langenecker S, Mullier F, Pavord S, Hermans C. European guidelines on perioperative venous thromboembolism prophylaxis: Patients with preexisting coagulation disorders and after severe perioperative bleeding. European Journal of Anaesthesiology. 2018; 35(2):96-107. doi: 10.1097/EJA.0000000000000725.

4. Chi G, Kalayci A, Cohen AT, Hernandez AF, Hull RD et al.. Extended-duration betrixaban versus shorterduration enoxaparin for venous thromboembolism prophylaxis in critically ill medical patients: an APEX trial substudy. Intensive Care Medicine. 2019; 45(4):477-87. doi: 10.1007/s00134-019-05565-6.

5. Pavon JM, Sloane RJ, Pieper CF, Colón-Emeric CS, Cohen HJ, Gallagher D. Poor adherence to risk stratification guidelines results in overuse of venous thromboembolism prophylaxis in hospitalized older adults. J Hosp Med. 2018; 13(6):403-4. doi: 10.12788/jhm.2916.

6. Stuck AK, Spirk D, Schaudt J, Kucher N. (). Risk assessment models for venous thromboembolism in acutely ill medical patients. A systematic review. Thromb Haemost. 2017; 117(4):801-8. doi: 10.1160/TH16-08-0631.

7. Gould MK, Garcia DA, Wren SM, Karanicolas PJ, Arcelus JI, Samama CM. Prevention of VTE in Nonorthopedic Surgical Patients: Antithrombotic Therapy and Prevention of Thrombosis, 9th ed: American College of Chest Physicians Evidence-Based Clinical Practice Guidelines. Chest. 2012; 141(2):227-77. doi: 10.1378/chest. 11-2297.

8. Saadi R, Brandt K, Madlinger R, Nerenberg S. Venous Tromboembolism Prophylaxis in Traumatic Brain Injure Patients. Critical Care Medicine. 2018; 46(1):790-9.doi:10.1097/01.ccm.0000529612. 93099.84.

9. Hachem LD, Mansouri A, Scales DC, Geerts WH, Pirouzmand F. Anticoagulant prophylaxis against venous thromboembolism following severe traumatic brain injury: A prospective observational study and systematic review of the literature. Clinical Neurology and Neurosurgery. 2018; 175:68-73. doi: 10.1016/j.clineuro.2018.09.032.

10. Bryce HE, Besien VR, O'Hara NN, Slobogean GP. Post-discharge adherence with venous thromboembolism prophylaxis after orthopedic trauma: Results from a randomized controlled trial of aspirin versus low molecular weight heparin. Journal of Trauma and Acute Care Surgery. 2018; 84(4):564-74. doi: 10.1097/TA.0000000000001771.

11. 11.Starr AJ, Shirley Z, Sutphin PD, Sanders D, Eastman A, Au B. Significant reduction of pulmonary embolism in orthopaedic trauma patients. Journal of Orthopaedic Trauma. 2019; 33(2):78-81. doi: 10.1097/BOT.0000000000001346. 
12. Miano TA, Cuker A, Christie JD, Martin N, Smith B. Comparative effectiveness of enoxaparin vs dalteparin for thromboprophylaxis after traumatic injury. Chest. 2018; 153(1):133-42. doi: 10.1016/j. chest. 2017.08.008.

13. Sumislawski JJ, Kornblith LZ, Conroy AS, Callcut RA, Cohen MJ. Dynamic coagulability after injury: Is delaying venous thromboembolism chemoprophylaxis worth the wait? Journal of Trauma and Acute Care Surgery. 2018; 85(5):907-14. doi: 10.1097/TA. 0000000000002048.

14. Murphy PB, Lau BD, Vogt KN, Cuker A. Venous thromboembolism prevention in emergency general surgery: a review. JAMA Surg. 2018; 153(5):479-86. doi: 10.1001/jamasurg.2018.0015.

15. Ruskin KJ. Deep vein thrombosis and venous thromboembolism in trauma. Current Opinion in Anaesthesiology. 2018; 31(4):215-18. doi: 10.1097/ACO. 0000000000000567.

\section{УДК 617.55-001-06:616.14-005.6/.7] - 037 ДИНАМИЧЕСКАЯ ПРОГНОСТИЧЕСКАЯ ШКАЛА ОПРЕДЕЛЕНИЯ СТЕПЕНИ РИСКА ВЕНОЗНЫХ ТРОМБОЗОВ И ЭМБОЛИЙ У ПАЦИЕНТОВ С ИЗОЛИРОВАННОЙ И ТЯЖЕ- ЛОЙ СОЧЕТАННОЙ ТРАВМОЙ ЖИВОТА}

Р.Л. Бохонко ${ }^{1}$, О.Б. Матвийчук ${ }^{1}$, Я.А. Король ${ }^{1}$, Н.P. Федчишин ${ }^{1}$, Т.М. Федоришин ${ }^{2}$

${ }^{1}$ Львовский национальный медицинский университет имени Даниила Галиџкого, кафедра хирургии и эндоскопии факультета последипломного образования,

г. Львов, Украина,

${ }^{2}$ Коммунальное некоммерческое предприятия «Клиническая больница скорой медицинской помощчи 2. Львова», г. Львов, Украина,

ORCID ID: 0000-0003-3859-0635,

ORCID ID: 0000-0002-5864-1535,

ORCID ID: 0000-0003-3664-3035,

ORCID ID: 0000-0003-0232-2778,

ORCID ID: 0000-0002-8683-1221,

e-mail:romanbokhonko@gmail.com

Цель. Целью исследования является улучшение результатов лечения пациентов с изолированной и тяжелой сочетанной травмой живота путем дифференцированной профилактики венозных тромбозов и эмболии за счет использования разработанной динамической прогностической шкалы определения степени их риска.

Материалы и методы. В основу работы положены результаты обследования и лечения 140 пострадавших ретроспективной, 105 пациентов проспективной и 57 травмированных группы проспективного прогнозирования с изолированной и тяжелой сочетанной травмой живота, в 2005-2017 годах.

Результаты. За ходом выполнения исследования и разработки выборки из 105 пациентов проспективной группы с изолированной и тяжелой сочетанной травмой живота, которые оперированы за период с 2012 до 2016 гг., верифицированы 27
$(25,7 \%)$ случаев тромбоза в бассейне нижней половой вены, из которых 10 ( 37,0\%) проявились клинически, а именно признакам отека конечности, пастозности и болевого синдрома. Анализ 48 показателей методом однофакторного регрессионного анализа выделил 18 предикторов, которые имели статистически достоверное $(\mathrm{p}<0,05)$ влияние.

С помощью статистического анализа создано объективизированную динамическую прогностическую шкалу, которая содержит перечень факторов риска ВТЭ перед операционным вмешательством и в послеоперационном периоде, а их прогностическую значимость выражено в баллах.

Выводы. Установлено 4 независимых фактора возникновения тромбоза глубоких вен в предоперационном периоде и 3 в послеоперационном периоде. Но основе независимых факторов создано объективизированную динамическую прогностическую шкалу прогнозирования риска венозных тромбозов и емболии. Внедрение в клинике объективизированной динамической прогностической шкалы степени риска ВТЭ и соответствующее применения профилактики позволили существенно снизить частоту этих осложнений с $25,7 \%$ до 7,1\% $(\mathrm{p}<0,05)$.

Ключевые слова: прогностическая динамическая шкала, тромбоз глубоких вен, венозные тромбозы и эмболии, изолированная травма живота, тяжелая сочетанная травма живота.

UDC 617.55-001-06:616.14-005.6/.71-037

\section{DYNAMIC PROGNOSTIC SCALE FOR VENOUS THROMBOSIS AND EMBOLISM RISK EVALUA- TION IN PATIENTS WITH ISOLATET AND SEVERE COMBINED ABDOMINAL TRAUMA}

R.L. Bokhonko ${ }^{1}$, O.B. Matviychuk ${ }^{1}$, Y.A. Korol ${ }^{1}$, N.R. Fedchyshyn ${ }^{1}$, T.M. Fedoryshyn ${ }^{2}$

${ }^{1}$ Danylo Halytsky Lviv National Medical University, Department of Surgery and Endoscopy faculty of Postgraduate Education, Lviv, Ukraine,

${ }^{2}$ Lviv City Emergency Hospital, Lviv, Ukraine, ORCID ID: 0000-0003-3859-0635,

ORCID ID: 0000-0002-5864-1535,

ORCID ID: 0000-0003-3664-3035,

ORCID ID: 0000-0003-0232-2778,

ORCID ID: 0000-0002-8683-1221,

e-mail: romanbokhonko@gmail.com

Abstract. Aim. To improve the results of treatment of patients with isolated and severe combined abdominal trauma by differentiated prophylaxis of VTE by the use of the developed dynamic prognostic scale for determining the degree of their risk.

Materials and methods. The work is based on the results of the examination and treatment of 140 patients of retrospective, 105 of prospective and 57 injured patients of prospective group with isolated and severe combined abdominal trauma, who underwent surgery in Lviv city center of thoraco-abdominal trauma (Surgical department 1), traumatology and neurosurgery depart- 
ments of Lviv city emergency hospital in 2005-2017. Diagnostic procedures and surgical interventions in all injured were performed urgently in terms defined by existing standards and protocols. At the time of admission, $86(81.9 \%)$ of the injured were in a moderately severe condition, $19(18.1 \%)$ - in severe one. In the preoperative period, correction of vital functions was performed taking into account the recommendations of adjacent specialists. All patients were assessed for anesthesiological risk according to the ASA score, and 101 (96.2\%) patients underwent surgical intervention using inhalation or non-inhalation anesthesia, in $4(3.8 \%)$ diagnostic procedures lasted 30-220 min (average - 123.8 \pm 42.6 ).

Results. During the analysis of 105 cases of prospective group of isolated and severe combined abdominal trauma, operated in 2012-2016, 27 (25.7\%) cases had thrombosis of the lower vena cava, of which 10 $(37,0 \%)$ manifested clinically - edema of the limb, pastosity and pain syndrome. One-factor regression analysis of 48 indicators had identified 18 predictors with a statistically significant $(p<0.05)$ effect on the onset of DVT in the lower extremities both in pre- and post-operative periods in isolated and severe combined abdominal trauma patients. Predictors, isolated by monofactor analysis, were calculated by a regressive sequential multivariate analysis of Wald. The numerical range was from -5.5 to +7.5 in the preoperative and from -8.5 to +6.5 - in postoperative period. In order to establish clinical efficacy, an objective dynamic predictive scale for assessing the risk of VTE in patients with isolated and severe combined abdominal trauma was tested in a group of 57 patients admitted in 2016-2017 without age and gender constraints, severity of injury $>16$ points for the ISS and $>2$ points on the AIS, absence of DVT of the lower extremities upon admission. Preoperatively, the sum of up to 10 points corresponded to the low grade of the VTE (probability of DVT - up to 2\%), 11-20 points - moderate (DVT - up to $20 \%$ ), more than 20 points - high (DVT $>60 \%$ ). Respectively, the risk was calculated after the operation: low - up to 20 points (DVT - $2 \%$ ), moderate 20-30 points (DVT $-2-25 \%$ ) and high - >30 points (probability of DVT $->65 \%$ ).

Conclusions. There are 4 independent factors of the occurrence of DVT in the preoperative period and 3 in the postoperative period. Using the independent predictive factors, an objectified dynamic prognostic scale for predicting the risk of VTE in patients with isolated and severe combined abdominal trauma has been worked out with light, moderate and high degree of risk (sensitivity $83.3 \%$, specificity $76.5 \%$ ). The introduction of an objectified dynamic prognostic scale of the risk of VTE in the clinic and use of prophylaxis significantly reduced the incidence of these complications from $25.7 \%$ to $7.1 \%$ $(\mathrm{p}<0.05)$.

Keywords: dynamic prognostic scale, deep vein thrombosis, venous thrombosis and embolism, isolated abdominal trauma, severe combined abdominal trauma. 